\title{
К анализу проекта федерального закона «О недрах»
}

\section{Селиверстов С.С.*}

Земля, недра, природные ресурсы являются основой жизнедеятельности человека, именно в таком качестве они и обозначаются в законодательных актах - достаточно указать на статью 9 Конституции РФ и статью 1 Земельного кодекса РФ. К основным источникам, регулирующим вопросы собственности на землю и энергетические природные ресурсы, можно отнести Конституцию РФ, Гражданский кодекс, Земельный кодекс, Закон РФ «О недрах», Федеральный закон «О соглашениях о разделе продукции» (далее - «Закон «О СРП») и еще около десяти законов и кодексов. Анализ нового проекта закона «О недрах» подтверждает важность совместимости прав на недра и прав на поверхлежащие земельные участки.

\section{- Земельный участок как объект права собственности.} \section{Соотношение гражданского и земельного законодательства}

Гражданский кодекс РФ определяет как правовые, так и пространственные пределы права собственности на земельный участок. Право собственности на земельный участок распространяется на находящиеся в границах этого участка поверхностный (почвенный) слой и замкнутые водоемы, находящиеся на нем лес и растения. Собственник земельного участка вправе использовать по своему усмотрению все, что находится над и под поверхностью этого участка, если иное не предусмотрено законами о недрах, об использовании воздушного пространства, иными законами и не нарушает прав других лиц.

При регулировании земельных отношений применяется принцип разграничения действия норм гражданского законодательства и норм законодательства земельного. При этом земельное законодательство регулирует земельные отношения, то есть отношения по использованию и охране земель в РФ. Таким образом, гражданско-правовой режим земель ограничивается установленными земельным законода-

' Селивёрстов Сергей Сергеевич - магистр права, аспирант кафедры международных проблем ТЭК Международного института зкономической политики и дипломатии МГИМО (У) МИд России. 
тельством рамками, в частности ограничениями оборота и требованиями по соответствуюшему использованию различных категорий земель.

\section{Правовые титулы на земельные участки и категории земель}

Правовые титулы на земельные участки установлены как в Гражданском, так и в Земельном кодексах РФ. Юридические лица могут приобретать право собственности, сервитут, а также арендовать земельные участки. Кроме того, Земельным кодексом предусмотрено семь категорий земель, в том числе земли сельскохозяйственного назначения, земли поселений, лесного и водного фонда, земли промышленности и энергетики. Земли определенной категории используются в соответствии с установленным для них целевым назначением.

Земли промышленности и энергетики входят в категорию земель специального назначения. Они располагаются за чертой поселений и используются или предназначены для обеспечения деятельности организаций и (или) эксплуатации объектов промышленности и энергетики. Земельным кодексом специально установлено, что организациям горнодобываюшей и нефтегазовой промышленности земельные участки для разработки полезных ископаемых предоставляются после оформления горного отвода, утверждения проекта рекультивации земель, восстановления ранее отработанных земель.

С 5 января 2005 года порядок перевода земель из одной категории в другую регулируется специальным законом - Федеральным законом от 21 декабря 2004 года № 172-Ф3 «О переводе земель или земельных участков из одной категории в другую». Законом устанавливается ряд требований и ограничений для перевода сельскохозяйственных и лесных земель в земли промышленности и энергетики. Закрепление данных требований имеет чрезвычайно важное значение для достижения правовой определенности в данной сфере.

Установлено, что для нужд энергетики перевод земель сельскохозяйственного назначения в другую категорию допускается в исключительных случаях, связанных, в частности, со строительством линейных объектов, в том числе линий электропередачи и трубопроводов, если линейные объекты размешены вдоль дорог и границ полей севооборотов и если кадастровая стоимость сельскохозяйственных угодий на 30 и более процентов меньше кадастровой стоимости среднерайонного уровня. В случаях, связанных с добычей полезных ископаемых и строительством линейных объектов при отсутствии других вариан- 
тов размещения, допускается перевод более ценных сельскохозяйственных земель, вплоть до земель, кадастровая стоимость которых на 30 и более процентов превышает кадастровую стоимость среднерайонного уровня.

\section{Вопросы платы за землю}

С 1 января 2005 года вступил в силу Федеральный закон от 29 ноября 2004 года № 141-Ф3 «О внесении изменений в часть вторую Налогового кодекса Российской Федерации и некоторые другие законодательные акты Российской Федерации, а также о признании утратившими силу отдельных законодательных актов (положений законодательных актов) Российской Федерации» (далее-«Ф3 № 141»). Указанным Федеральным законом вводится в действие Глава 31 Налогового кодекса «Земельный налог» (далее - «Глава $31 »)$, а также устанавливаются ряд связанных с этим переходных положений.

Вместе с тем, исходя из содержания статьи 7 Федерального закона от 29 июля 2004 года № 95-Ф3 «О внесении изменений в части первую и вторую Налогового кодекса Российской Федерации и признании утратившими силу некоторых законодательных актов (положений законодательных актов) Российской Федерации о налогах и сборах", земельный налог, положения о котором закреплены в Главе 31, может быть установлен, но не может быть введен в действие ранее 1 января 2006 года. Налицо, таким образом, определенная внутренняя коллизия между предписаниями Налогового кодекса.

При рассмотрении вопросов платежей за землю важное значение имеет арендная плата за использование земельных участков. Статьей 3 Федерального закона от 25 октября 2001 года № 137-Ф3 «О введении в действие Земельного кодекса Российской Федерации» установлен льготный размер арендной платы за использование земельных участков, находящихся в государственной или муниципальной собственности и занятых объектами транспортных систем естественных монополий, а также земельных участков, находящихся в государственной или муниципальной собственности и расположенных в районах Крайнего Севера. В указанных случаях размер арендной платы не может быть выше размеров ставок земельного налога, установленных для земель промышленности, энергетики, транспорта, связи, радиовешания, телевидения, информатики, земель для обеспечения космической деятельности, земель обороны, безопасности и земель иного специального назначения. 
Арендная плата, равная ставке земельного налога, является важным стимулом в развитии трубопроводного транспорта, систем электропередачи, а также любой деятельности компаний сферы ТЭК в районах Крайнего Севера. Известно, что в США и европейских странах расходы энергетических компаний, в том числе осуществляющих деятельность по транспортировке энергоносителей, на приобретение земельных прав составляют значительную часть их бюджета'

Кроме того, предусмотренная Земельным кодексом РФ возможность изьятия земель для государственных нужд может быть использована компаниями по транспортировке энергоносителей для получения низких размеров арендной платы также в случах, когда собственником земли окажется частное лицо.

\section{Связь правового режима недр и режима земель}

Законодательство о недрах также регулирует отдельные аспекты земельных отношений. Так, предоставление лицензий на пользование недрами осуществляется при наличии предварительного согласия органа управления земельными ресурсами либо собственника земли на отвод соответствующего земельного участка для целей недропользования. Если собственником является физическое или юридическое лицо, получение такого согласия возможно в договорном порядке.

Существует и другой вариант. При обнаружении в недрах полезных ископаемых земельные участки, необходимые для проведения работ, связанных с использованием недр, временно или постоянно могут отчуждаться для государственных нужд с возмещением собственникам их стоимости. Затем указанные земельные участки могут быть переданы в пользование субъекту, непосредственно осуществляющему разработку недр в соответствии с лицензией.

Налицо, таким образом, два вида согласования интересов недропользователя и собственника земли - экономический (договорный) и административный. При этом возможность отчуждения земли для государственных нужд может быть использована возможным недропользователем в качестве инструмента давления на собственника земли.

Кроме того, Законом «О недрах» определены условия застройки площадей залегания полезных ископаемых и закреплено право пользователя недр ограничивать застройку таких площадей в границах предоставленного ему горного отвода.

\footnotetext{
${ }^{\mathrm{i}}$ См., напр.: Природный газ / Под. ред. Р. Басби. М.: Бизнес-Олимп, 2004.
} 
Исходя из вышеуказанного, можно сделать вывод о том, что недропользователь обладает своего рода сервитутными правами на расположенный над верхней границей горного отвода земельный участок. В указанном правомочии недропользователя находит отражение связь правового режима недр, а точнее - заключенных в них полезных ископаемых, в том числе энергетических ресурсов, с правовым режимом земли.

\section{Проект закона «О недрах»: \\ В чем юридическая новелла?}

В конце 2004 г. Министерством природных ресурсов РФ был подготовлен рабочий проект нового федерального закона «О недрах», а в марте 2005 г. - его обновленная версия ${ }^{2}$ (далее - «Проект»).

Вопросы применения гражданско-правового метода

К ключевым концептуальным отличиям Проекта можно отнести прежде всего установление в качестве приоритетного гражданскоправового метода регулирования имушественных отношений недропользования. Вместе с тем формулировка общего принципа, предложенная в пункте 6 статьи 2 Проекта («Имущественные отношения, возникающие при использовании и охране недр и не основанные на административном или ином властном подчинении, регулируются гражданским законодательством с учетом положений настояшего Федерального закона»), представляется не совсем удачной вследствие ее неоднозначности. Очевидно, что содержание понятия «имушественные отношения, основанные на административном или ином властном подчинении» может быть истолковано по-разному. В любом случае соответствующее толкование должно опираться на иные положения Проекта, отчасти раскрывающие смысл приведенной выше формулировки.

\section{Договор пользования участком недр}

Проектом предусмотрено, что право пользования участком недр может возникнуть на основании договора пользования участком недр (далее - «Договор пользования»), заключаемого с пользователем недр уполномоченным Правительством Российской Федерации федеральным органом исполнительной власти либо полномочным органом исполнительной власти субъекта Российской Федерации. Договор пользования заключается с победителем торгов-аукциона на право заключения такого договора.

\footnotetext{
${ }^{2}$ http://www.mnr.gov.ru/part/?act=more\&id=138\&pid=45
} 
По Договору пользования одна сторона (Российская Федерация, а по участкам недр местного значения - соответствующий субъект Российской Федерации) обязуется предоставить другой стороне (пользователю недр) участок недр за плату во временное пользование или во временное владение и пользование. Процедура заключения Договора пользования и отношения, возникающие в процессе реализации закрепленных в нем соглашений, регулируются в соответствии с нормами гражданского права.

Данные нормы, несомненно, представляют собой концептуально иной подход к отношениям в сфере недропользования. Государствособственник выступает в качестве стороны гражданско-правовых отношений, характеризующихся автономией воли и равенством сторон. При этом подобный договорный режим предусматривается не в качестве исключения для отдельных проектов, подобно режиму СРП, а в качестве общего правила.

\section{Соотношение Договора пользования с другими основаниями недропользования}

Наряду с Договором пользования Проектом предусмотрено еще одно основание пользования участком недр - лицензия, выдаваемая в соответствии с решением уполномоченных органов. Следует отметить, что соотношение двух вышеприведенных оснований недропользования установлено недостаточно четко. Из положений Проекта нельзя точно определить, в каких случаях предоставление участка недр должно осуществляться на основе Договора пользования, а в каких на основе лицензии. Представляется, что необходимые критерии для разграничения применения Договора пользования и лицензии должны быть установлены именно законом, а не различными подзаконными актами.

Интересно отметить, что в Проекте употребляется понятие «договор пользования участком недр» и не используются понятия «концессионный договор» или «концессия». С учетом продолжающейся разработки проекта закона о концессиях является небезынтересным, как в теоретическом, так и в практическом плане, рассмотрение вопроса о соотношении данных категорий.

Предметы Договора пользования, предусмотренного Проектом, и концессионного договора во многом схожи. В обоих случаях речь идет о передаче частному лицу монопольных прав на эксплуатацию недр. Вместе с тем предмет концессионного договора несколько шире; 
он может включать в себя помимо права пользования недрами иные монопольные права государства. Таким образом, с предметной точки зрения Договор пользования является частным случаем концессионного договора.

В качестве отличительных особенностей концессионного договора отмечается также наличие стабилизационной оговорки. Как отмечают исследователи, «экономическим содержанием договора концессии... явилось бы закрепление характеристик налоговой системы (номенклатура и ставки налогов, механизмы налогового администрирования), существующих на дату заключения концессионного договора, на весь период концессии. Основная цель такого содержания договора предсказуемость действий его сторон за счет детальной регламентированности (прописанности в договоре) их действий (в первую очередь - Государства) и механизма разрешения споров между сторонами» ${ }^{3}$. В рамках концессии «инвестор должен иметь государственные гарантии стабильности для своих инвестиций - стабилизационная оговорка на период действия проекта, национальный режим, неизменность налогов и сборов и т.д. ${ }^{4}$.

- В Проекте отсутствуют положения, которые предусматривали бы включение в Договор пользования стабилизационной оговорки. Подобное отличие от классического режима концессии не является исключительно формальным, поскольку предусмотренный Проектом режим Договора пользования не предоставляет пользователю недр гарантий стабильности и предсказуемости условий его деятельности.

В плане стабильности положения пользователя недр (инвестора) предпочтительнее остается режим СРП. Вместе с тем при сохранении после принятия Проекта сложившегося в настоящее время соотношения Закона «О недрах» как общего закона и Ф3 «О СРП» как специального закона режим СРП будет применяться в ограниченном числе проектов в качестве исключения из обшего режима Договоров пользования.

\section{Ограничительный режим пользования недрами}

\section{для иностранцев}

Запрет на приобретение права пользования недрами субъектами иностранного права направлен прежде всего на усиление контроля за

\footnotetext{
${ }^{3}$ Конопляник А.А. Реформа нефтяной отрасли России (налоги, СРП, концессии) и их последствия для инвесторов, М.: Олита, 2002. С. 123-124.

+ Линник Л.К. Налоговое регулирование при пользовании недрами в России и зарубежных странах. М.: ВНИИВС, 2002. С. 109.
} 
деятельностью недропользователей со стороны государственных органов и максимизацию налоговых поступлений. Иностранные фирмы, намеревающиеся приобрести право пользования недрами на территории Российской Федерации, будут вынуждены в случае принятия Проекта учреждать дочерние предприятия на территории Российской Федерации. Это, несомненно, приведет к увеличению налоговых и административных расходов иностранного инвестора, что может снизить инвестиционную привлекательность бизнеспроектов, основанных на Договоре пользования и лицензировании.

При этом Проектом предусмотрены исключения для инвесторов, заключающих соглашения о разделе продукции. Таким образом, режим СРП может явиться более оптимальным для иностранных инвесторов также с точки зрения административной организации их деловой активности на территории Российской Федерации.

Режим Договора пользования предусматривает встраивание всех аспектов деятельности пользователя в систему российского права. При этом в отсутствие стабилизационной оговорки условия указанной деятельности будут изменяться сообразно изменениям действующего в текущий момент законодательства.

\section{Оборотоспособность права пользования}

Статья 16 Проекта устанавливает, что владение и (или) пользование недрами в Российской Федерации осуществляется на основе права пользования участком недр. Участок недр не может быть предметом гражданского оборота. При этом, согласно статье 19, право пользования участком недр является объектом гражданского оборота.

В статье 54 Проекта подробно урегулирована процедура передачи права пользования недрами, возникшего на основании Договора пользования. Указанная процедура носит разрешительный характер.

Очень важная новелла содержится в статье 55 Проекта, в которой делается ряд исключений из вышеуказанных положений, регулирующих переход права пользования недрами для случаев залога. Залогодержателем по договору залога, предметом которого является возникшее на основании договора право пользования участком недр; может быть субъект предпринимательской деятельности вне зависимости от его соответствия требованиям, предъявляемым к пользователям недр федеральными законами и решением о проведении аукциона по данному участку недр, если договор залога не предусматривает передачу права пользования участком недр залогодержателю в течение срока 
исполнения обеспечиваемого залогом обязательства. При передаче права пользования недрами в залог не применяется также правило об универсальном правопреемстве.

Указанные правила о залоге могут значительно облегчить возможность привлечения заемного капитала и привести к снижению его стоимости при реализации проектов в сфере недропользования. В результате это способно привести к снижению себестоимости получаемых при разработке месторождений полезных ископаемых.

\section{Другие новеллы Проекта}

В качестве отдельных новшеств, предусмотренных Проектом, следует отметить статью, целиком посвященную раскрытию основных понятий, в частности новому определению недр: «часть земной коры, расположенная ниже почвенного слоя, а при его отсутствии - ниже земной поверхности и дна водоемов и водотоков, простирающаяся до центра Земли».

Также установлено, что на основе права пользования участком недр может осуществляться не только правомочие пользования, но и правомочие владения недрами. Использование понятия «владение недрами» c формально-юридической точки зрения в гораздо большей степени соответствует сущности таких видов деятельности, как эксплуатация подземных нефте- и газохранилиш субъектами предпринимательской деятельности.

Несомненно, Проект содержит ряд существенных недостатков. Основными из них являются возможность усиления административно-правового элемента в регулировании и отсутствие гарантий стабильности налоговых и административных предписаний для пользователей недр. Несмотря на это, Проект несет в себе массу положительных элементов. Либерализация оборота права пользования недрами также является одним из ключевых начал гражданско-правового регулирования отношений недропользования. При этом подобная либерализация не обязательно ведет к ушемлению интересов государства как собственника природных ресурсов. Представляется, что именно в рамках гражданско-правового подхода у различных субъектов отношений по использованию недр имеется возможность нахождения наиболее оптимального баланса интересов. Вместе с тем очевидна необходимость внесения в Проект целого ряда поправок, прежде чем он сможет вступить в силу. 